\title{
Compulsory Regulation of CSR: A Case Study of Nigeria
}

\author{
Bethel U. Ihugba ${ }^{1}$ \\ ${ }^{1}$ University of Wales Cardiff, Greenwich School of Management London \\ Correspondence: Bethel U. Ihugba, University of Wales Cardiff, Greenwich School of Management London. \\ E-mail: bethelihugba@yahoo.com
}

Received: March 12, 2012 Accepted: April 5, 2012 Online Published: May 11, 2012

doi:10.5539/jpl.v5n2p68 ～URL: http://dx.doi.org/10.5539/jpl.v5n2p68

\begin{abstract}
The language of CSR is mostly voluntary. Commentators, business organisations and lobbyist have not relented in defining it as a voluntary practice. But events so far suggest that an entirely voluntary concept of CSR is no longer tenable. Particularly in the petroleum industry in developing countries, companies have failed to take CSR initiatives to create sustainable business practices, or contribute to the development of their host states. Rather, they perceive CSR as philanthropic activity for which they expect congratulations and tax breaks but fail to take responsibility for the aftermath of their activities or embark on proactive practices that will prevent those negative fallouts of business practices. However, in Nigeria a bold step was taken to introduce compulsory regulation of CSR into corporate governance via the NEITI Act 2007. This paper examines this initiative and suggests ways to increase its success.
\end{abstract}

Keywords: CSR, regulation, stakeholder engagement, extractive industries, Nigeria

\section{Introduction}

Corporate Social Responsibility(CSR) classically described as the concept that business has an obligation to society that extends beyond its narrow obligation to its ownersor shareholders (Bowen, 1953), has generally been promoted as voluntary (McGuire, 1963; European Commission, 2001; Commission of the European Communities, 2006). Only a few definitions contemplate compulsory regulation (Carroll, 1991; Baker, 2010; Bowen, 1953) or the concept of coercion (Utting, 2005; Wettstien, 2009). The dominant argument is that the desire of organisations to maintain legitimacy is sufficient to promote CSR (Tuzzolino and Armandi, 1981; Powell and DiMaggio, 1991; Elsbach, 1994). Legitimacy, in summary, refers to the positive perception the society has of an organisation arising from, among other things, its good CSR profile (Shocker and Sethi, 1974; Deegan, 2002). However, there are arguments that legitimacy can be manipulated (Elsbach, 1994, Suchman, 1995), suggesting it may not necessarily be a good indicator of social responsibility. The strength of the argument and the ambiguity prevalent in the CSR discourse is illustrated by the result of a recent CSR symposium "Corporate Social Responsibility on trial" (2010). At the symposium, Baden as advocate and Harwood as opponent made strong arguments for and against the validity of voluntary CSR which split the "jury" of CSR researchers 50/50. This ambivalence suggests the need to reconceptualise the CSR and regulation debate.

The research question here is therefore whether compulsory regulation can improve CSR. To answer this question, the paper explores compulsory regulation as provided by Nigerian Extractive Industry Transparency Initiative (NEITI) Act 2007. The remainder of this paper is structured as follows. Firstly, literature reviews of the theoretical concepts of stakeholder engagement and regulation is conducted. Secondly, a detailed discussion of Nigeria and its CSR related regulation of Nigerian Extractive Industry, particularly the petroleum subsector. This helps to highlight the supposed justification for the stricter CSR regime in Nigeria. Next is a discussion of the research methodology used in conducting the research. And in the penultimate section, research findings and discussion is presented simultaneously. The paper concludes by giving a summary of answers to the research question and policy suggestions.

\section{Literature Review}

\subsection{Stakeholder Engagement}

Arnstein's work on community participation in public governance provides good scale for measuring stakeholder engagement. It describes participation as one where the stakeholders are involved in setting the rules for 
participation and in choosing who represents them. To be effective, these rules must create a fair and equal playing field for all participants (Arnsteins, 1969). This is especially important where power imbalance exists as is the case between the oil industry (government and oil companies) and the Nigerian populace. The Nigeria Government and oil companies are grouped together because (1) the government has majority shares in the oil companies and (2) both have the power to influence what happens in the industry.

Stakeholder engagement derives from stakeholder theory. Stakeholder theory explains the relationship between organisations and their immediate society. It contends that organisations should aim to satisfy the interest of persons other than shareholders (Freeman, 1984; Foster and Jonker, 2000). These persons are termed stakeholders and are defined as those "who can affect, or are affected by the achievement of an organization's purpose" (Freeman, 1984, p 46), or have legitimate claim on an organisation (Hill and Jones, 1992) and can exact influence over the organisation (Carroll, 1993), or are exposed to risk [financial, human, or environmental] (Clarkson, 1995). Based on this theorisation, organisations are encouraged to consider stakeholders in carrying out their activities.

The approach suggested for manifesting this consideration is Stakeholder Engagement, defined by Institute of Social and Ethical Accountability (ISEA 1999, p.91) as "the process of seeking stakeholder views on their relationship with an organisation in a way that may realistically be expected to elicit them"; by Andriof and Waddock (2002, p.42) as "trust-based collaborations between individuals and/or social institutions with different objectives that can only be achieved together" and by Gable and Shireman (2005, p.9) as "a process of relationship management that seeks to enhance understanding and alignment between company and their stakeholders".

Arnsteins (1969) analysis of stakeholder engagement identified eight engagement levels and classified them into three groups of non-participation (comprising of manipulation and therapy), tokenism (comprising of informing, consultation and placation) and citizen power (comprising of partnership, delegated power and citizen control) (see table.1). According to Arnstein, real engagement starts within the citizen power group when stakeholders negotiate distribution of power with power holders as partners and not as subordinates. At the citizen power level stakeholders are independent and there is transparency in the issues, details and process of engagement. Also it is when they mutually set up rules and submit same to an independent arbiter created by regulation or binding agreement. A stakeholder engagement that meets the level of citizen power has the benefit of enforceability, power balance, fair participation, sustainability and is more likely to achieve results than an imposed or skewed participation (Arnstein, 1969; Schneider, 1999)

Authors like Cumming (2001 and 2002) and Luis (2005), have written conceptual papers promoting Arnsteins stakeholder engagement model. This paper is using this concept to examine stakeholder engagement in the Nigeria petroleum industry within a compulsory regulation framework i.e. NEITI framework.

\subsection{Compulsory Regulation}

Some writers contend that CSR is akin to promotion of fundamental human rights e.g. right to property, dignity of labour and good livelihood, and thus ethically necessary, morally obligatory and within the sphere of compulsory regulation (Amao, 2008; Utting, 2005; Wettstien, 2009). Compulsory regulationrefers tolegislative enactments or judicial judgements prescribing roles and sanctions. The advocacy for compulsory regulation is seen as a sure way to promote transparency and accountability and also regain the trust of the public (Muller, 2010; Shaxson, 2009; Pritchard, 2003). This is because evidence has shown that when companies and government are left unchecked they do become oppressive and irresponsible [Enron, the recent BP spillage crisis] (Pritchard, 2003). Compulsory regulation also has the benefits of certainty, enforceability (Gatto, 2002), fair play andstakeholderempowerment (DBIS, 2009). In stakeholder engagement, compulsory regulation will define duties, provide for the rights of parties, and create order and predictability in procedure (Gatto, 2002). Compulsory regulation is usually universal (covering the entirety of the identified population). This universality and enforcement feature is what ensures the right of aggrieved parties to seek remedy and deters deviance (Note 1).

Compulsory regulation has its limitations. These include high cost (Glaser and Gyourko 2002), difficulty of access to justice and procedural requirements. The decades of wrangling in the Wiwa (Note 2), and Re Bhopal (Note 3) cases testify to these problems. In Bhopal case decision was stalled for over 25 years (Singh, 2010). There is also lack of court precedents to rely on because few CSR cases have been conclusively decided in courts of law. Another limitation is the reactive nature of regulation. Laws are generally unable to anticipate some situations. They are written, or in the case of court judgements reached in retrospect or reactive instead of 
proactive (Ward 2000, 2002; Gatto 2002; Pritchard, 2003). There are also drafting complexities arising from tokenism and inelegant attempts to pacify lobbyists (Arnstein 1969, see table 1).

Table 1. Levels and features of Stakeholder engagement

\begin{tabular}{|l|l|l|l|}
\hline SN & $\begin{array}{l}\text { Levels of } \\
\text { Stakeholder Engagement }\end{array}$ & Group & Benefits \\
\hline 1 & Manipulation & Non-participation & None \\
\hline 2 & Therapy & Non-participation & None \\
\hline 3 & Information & Tokenism & $\begin{array}{l}\text { Provides information } \\
\text { but does not aid } \\
\text { stakeholder } \\
\text { without more }\end{array}$ \\
\hline 4 & Consultation & Tokenism & As Above \\
\hline 5 & Placation & Tokenism & $\begin{array}{l}\text { As above } \\
\text { and } \\
\text { usually reactive }\end{array}$ \\
\hline 6 & Partnership & & Fair participation \\
\hline 7 & Delegation & Citizen power & Power balance \\
\hline 8 & Stakeholder Control & Citizen power & $\begin{array}{l}\text { Enforceability } \\
\text { Sustainability }\end{array}$ \\
\hline
\end{tabular}

Source: Adapted from Arnstein, 1969, p. 1

However, despite these seeming limitations, there appears to be more support for compulsory regulation for its potential to create trust and fairness in business relations (Muller, 2010; Shaxson, 2009; Pritchard, 2003).The question, however, is can it work for Corporate Social Responsibility?

\section{Research Background}

\subsection{The Nigerian Oil and Gas Industry}

Nigeria has been producing oil for over fifty years and Liquefied Natural Gas (LNG) since 1999. In 2006, Nigeria's high quality crude contribution amounted to $3 \%$ of global production at a production rate of 2.4 million barrels per day (Vines, Wong, Weimer and Campos, 2009). In August 2008, Nigeria had 36.2 billion barrels in oil reserve second only to Libya amongst African nations (BP review, 2009). And in 2008 Nigeria exported a total of 362,000 barrels per day of crude oil (approximately 7.7\% of USA crude oil import for that year) to the United States (Shaxson, 2009).

Nigerian oil and gas policy is complex and mired in political interventionism and corruption. At one time the former president, Obasanjo was both president and minister for petroleum resources (Muller, 2010) apparently to reduce fraud. But this has in no way reduced the gross mismanagement in the industry (NEITI Audit 1999-2004). Also the flaunting of wealth by political leaders, far above their salary and the poverty of the ordinary citizens, further suggests gross mismanagement, fraud and self-aggrandizement. In fact, several former political officeholders have been charged and or convicted of fraud both in Nigeria and abroad (Balogun, 2010; BBC, 2009, 2012; Business Day, 2010).

Oil companies are also culpable. Despite the pollution, caused by gas flaring and oil spillages, oil companies seem overly interested in financial benefit without regard to the deprivations and violence traceable to their activities (Frynas, 2005, Muller 2010; Eweje, 2006; Ed Kashi, 2010). Companies are required to pay tax and make standing commitment in providing developmental infrastructures but it appears that even the requisite tax are avoided and expert accountants are employed to cover up the evasion (NEITI audit 1999-2004; 2005).

This is despite the series of agencies and regulations established to ensure that the country's oil and gas resource is responsibly managed. Prominent among these agencies and departments include the Nigerian National 
Petroleum Corporation (NNPC) and Department of Petroleum Resources (DPR), the Crude Oil Marketing Department (COMD), the National Petroleum Investment Management Services (NAPIMS), and the Pipelines and Products Marketing Company (PPMC) all within the NNPC. Despite all these agencies, the Nigerian Extractive Industry is very closed, corrupt, and unaccountable. However, there is the general believe that transparency in revenue collection will expose any lapse and provide opportunity to remedy the situation, hence the introduction of NEITI.

\subsection{Why a Legislative Option?}

The Nigerian government bought into the global Extractive Industries Transparency Initiative (EITI) in 2004 and promulgated the NEITI Act 2007 to enforce the mandate of NEITI. The hope was that the Act will promote accountability, transparency and stakeholder engagement that will stimulate balanced social development. The objective of the global EITI is to promote transparency and engagement with stakeholders in the oil and gas producing countries in order to reduce the high incidence of economic underperformance, conflict and poor governance in such countries (EITI n.d).

In Nigeria, Private Income Tax [PIT], from the organised and public sector, shares in the $20 \%$ contribution from sectors other than petroleum. Hence development projects and governance are hugely reliant on oil and gas revenue. For instance the 2009 budget reported that oil-related revenue accounts for $80 \%$ of the aggregate projection for Federation Account receipts in 2008 while non-oil sources of revenue accounted for $20 \%$ (Nigerian Budget 2009). This means that any disruption of oil revenue automatically disrupts the Nigerian economy. This is reflected in the preamble to the 2009 budget where the government blamed the Niger Delta crisis for the fluctuation in the oil revenue and the reduction in the expected income for that year (Nigerian Budget 2009). Also recently the chairman of the Revenue Mobilization, Allocation and Fiscal Commission (RMAFC), [Note 4] Mr Mahmud Tukur (Christian, 2010), lamented the disregard by the executive and legislature, of due process and regulatory provisions. He said this is possible because the matrix of the Nigerian polity does not allow stakeholders, in this case citizens, to participate in governance. Using the petroleum industry as an example, he lamented the lack of accountability and transparency and suggested that stakeholders should be more involved in the industry to ensure transparency. Mr.Tukur's statements confirm that the major problems faced by this sector, which create the environment for mismanagement, fraud and embezzlement are lack of enforceable laws, none engagement of stakeholder, lack of transparency and no accountability. It appears therefore that the NEITI Act can meet these objectives because it seeks to use stakeholder engagement to create environment for transparency and accountability in the extractive industry.

\subsubsection{Objectives of NEITI}

NEITI aims to ensure the "following of due process and achievement of transparency in the payments by extractive industries to government and government linked entities; and in the revenue received and reported by those governments and entities" (NEITI handbook 2005, p.4). NEITI is premised on the logic that policy makers need authentic financial information to make right policy decisions, and the citizens also need the same information to decide on whom to entrust with the responsibility of making policies and to identify when good policy is made. The hope is that transparency in the oil industry will translate to other benefits like; informed democratic debate, accountability, economic management and forward planning, a conducive investment environment for both national and Foreign Direct Investment, and adequate collection and management of revenue (NEITI Handbook 2005).

\subsubsection{Before NEITI}

Before NEITI, Nigeria collected and recorded oil and gas revenue by other methods that proved to be inefficient, especially in the area of transparency and accountability. The methods relied mostly on trial and error and without requirement for publication or engagement with stakeholders. This is attributed to Nigeria's long military dictatorship when heads of state were accountable to no one. However, since civilian governance there have been some improvements, although not fully consolidated (Christian, 2010).

The lack of transparency and accountability is illustrated by a recurring and disturbing findings from the NEITI audits (1999-2004 \& 2005) which showed that the agencies responsible for accounting for both physical quantity of oil produced and exported, and the revenue accrual had no reliable data. They relied on data provided by oil companies. Ironically these companies had histories of falsifying records and false accounting (Donovan, 2010). This is one of the problems the Act hopes to resolve.

The two most important methods used before NEITI were (a) publication of company accounts and (b) audits and tax returns. These methods are briefly discussed below. 


\subsubsection{Company Accounts and Audits}

The Nigerian Company and Allied Matters Act (CAMA) 1990, Part A, Part xi and xii, requires that all companies, including oil companies in operation in the country must prepare annual financial accounts which must then be audited by independent third parties. However, this was not working with regards to the oil industry because of two major shortcomings. Firstly, the accounts were shrouded in secrecy because of confidentiality provisions. This deprived government agencies and civil society of data with which to hold the companies and politicians accountable or question corporate tax evasion. Secondly, the independence of the third party auditors was questionable. Most of the so called expert auditors were already retained by the oil companies. Also, the oil companies could afford the high fee of accountants and auditors who could doctor the records. This was the general perception. The massive corruption of some state officials justifies the speculation that the auditors were in collusion with corrupt companies and government officials to loot the treasury. This is because they could not have stolen the alleged amounts without some accounting fraud (see Christian, 2010; Obuah 2010; Ohia, 2010; BBC, 2010; 2012)

\subsubsection{Tax/ Payment Returns}

It is also a legal requirement for companies to file annual tax returns to the Federal Inland Revenue Service (FIRS) which show payments or tax due to the government. For oil companies it was confidential and subject only to audit by the FIRS and NAPIMS. This circumstance subjects the process to the same setbacks of agency problem and corruption. The confidentialityclause created an environment for fraud and made it impossible for stakeholders to access information with which to engage meaningfully with the industry (Arnstein 1969, Schneider 1999).

\subsubsection{Post-NEITI Act 2007}

The main expectations from the NEITI Act were that it would enforce accountability and transparency in the oil industry. It was hoped that this would be achieved by creating a stakeholder engagement framework in the form of the NSWG and making publication of payments to the government a compulsory requirement.

\subsubsection{National Stakeholders Working Group (NSWG)}

The National Stakeholders Working Group (NSWG) as NEITI's governing body is responsible for developing a framework for achieving NEITI's mandate (Section 5, NEITI Act). These objectives include ensuring due process and transparency; monitor and ensure accountability; eliminate all forms of corrupt practices; ensure transparency and accountability by government in the payments made by all extractive industry companies to the Federal Government and statutory recipients and finally ensure conformity with the principles of EITI (section 2).

The NSWG is created to involve the stakeholders (citizens) in the management of the revenue of the country and reduce irresponsibility or oversee the political elites who have shown that they cannot be trusted to remain responsible (Muller, 2010). To ensure that it is truly composed of stakeholders, the Act requires that it consists of people and professionals who have direct relationship and knowledge about the extractive industry. According to section 6 (2) (a) of the Act, this include a secretary, one person from each of the six geopolitical zones and 4 other persons representing labour unions, extractive industry experts, extractive industry companies and the civil society.

\subsubsection{Compulsory Provisions of NEITI}

Section 16 creates sanctions against breach of NEITI provisions. The sanctions are against companies or their officials and government officials who give false information or report, render false statement or account, refuse or delay to render statements or account that result in loss of revenue to the federal government of Nigeria. According to the Act, a company found guilty of any of these offences will be liable to the equivalent of 200,000USDfine, recovery of the lost revenue and may lose its license to operate. Directors of guilty companies, unless otherwise proved innocent, and colluding government officials, are also liable to a fine ofthe equivalent of 30,000 USD and or two years imprisonment.

\section{Methodology}

This paper uses the NEITI regulation and the NEITI body as case studies (Easterby-Smith, 2008; Sotiorios, 1998) because it gives opportunity for understanding the phenomenon in question (De Vaus, 2002). Qualitative data is sourced from three major primary sources, the provisions of the NEITI Act 2007, semi-structured interviews with relevant stakeholders consisting of staffs of NEITI, NSWG, consultants and analysis of documents (NEITI Audit reports) and news reports on or related to NEITI. The Act provides the letters of the law while the interviewees give account of their experience and opinions on the functionality and success of both the 
legislation and NEITI as an institution. The audit and news reports give contemporaneity and collaborates the interview data.

Eight interviews were sourced for this paper. These include 3 members of the NSWG, 3 senior staffs of NEITI, 1 NEITI consultant and an excerpt from a newspaper interview granted by a former NEITI secretary. These respondents are anonimized for confidentiality (See table 2 for anonimized respondents). The interview took an average of one hour for each respondent. Some were interviewed again to clear any ambiguity.

Table 2. Anonimized respondents

\begin{tabular}{|l|l|l|}
\hline$\#$ & Respondent & Code \\
\hline 1 & NEITI Audit officer & NA \\
\hline 2 & NEITI Consultant & NC \\
\hline 3 & Senior NEITI staff & NATLOG \\
\hline 4 & NEITI NSWG Member & NSWG1 \\
\hline 5 & NEITI NSWG Member & NSWG2 \\
\hline 6 & NEITI NSWG Member & NSWG3 \\
\hline 7 & Former NEITI secretary & FNS \\
\hline 8 & A NEITI Director & ND \\
\hline
\end{tabular}

The documents included NEITI audit reports and news reports which gave contemporaneity to other data and help to recreate the context of the research and data. Although, the audit reports are not independent reports, it is accepted practice to use organisations' own report as data to study veracity of their claim. Authors like Gutherie and Parker (1989), Patten (1991, 1992), Deegan and Rankin (1996) and Neu, Warsame, and Pedwell, (1998) have all relied on internally produced reports to study an organisation.

These sources have four very important advantages. First, for documents, they present data that are well thought through (Creswell, 2003). Secondly, they preserve the nuances and intentions of the documents (Silverman, 2006). Thirdly, they are time saving, unobtrusive and minimises loss of meaning during transcription (Silverman, 2006; Creswell 2003). Interview responses on the other hand provide the paper with detailed and contemporaneous data and allows for clarification on ambiguities (Silverman, 2006). However, it has the disadvantage of being costly, time consuming and susceptible to misinterpretation during transcription (Silverman, 2006). To avoid this from happening the respondents' permissions were obtained for the interview to be recorded. These recordings are continually referred to support propositions. And finally, each of the three sources, interview, corporate documents and news reports, collaborate one another and strengthens the veracity and validity of the research (Patton, 2002).

For purposes of integration the discussion is conducted simultaneously with the findings. This helps to maintain a chain of evidence. Also for purposes of clarity, the discussion follows the headings of (1) stakeholder engagement (2) enforcement (3) transparency (4) accountability and (5) social development. These headings are chosen because they reflect the objectives of NEITI and how it hopes to achieve corporate social responsibility. For instance Stakeholder engagement paves way for social development (Arnstein, 1969; Schneider, 1999) while transparency, enforcement and accountability (elements of compulsory regulation) on the other hand are strategies to ensure that stakeholder engagement actually lead to social development. Transparency ensures that all stakeholders are fully informed. Enforcement ensures that rules are adhered to while accountability ensures that defaulters or even adherents take responsibility for their actions, good or bad.

The research regularly quotes from the source e.g. interview responses, sections of the NEITI law or news reports to maintain validity, specifically in the authenticity of the context and data. The newspaper reports also help contextualise the research findings (Creswell, 2003).

\section{Findings and Discussion}

As indicated above, findings are presented and discussed simultaneously under the headings of stakeholder engagement, Enforcement, Transparency, Accountability and Social development. 


\section{a. Stakeholder Engagement}

Section 6 (1) NEITI Act 2007, empowers the president to appoint not more than 14 persons as representatives of different stakeholder groups into the NSWG. The NSWG are to be appointed from extractive industry companies, civil society, labour unions in the extractive industries, experts in the extractive industry and one person each from the six geopolitical zones of Nigeria. The Act gives the president power to appoint the NSWG without any reference to the stakeholder constituencies or the National Assembly.

According to a NC (a respondent), this provision is dangerous because it wrongly assumes that the president is incorruptible and law abiding. However, corruption amongst the politicians (seeBBC, 2010; 2012,Christian, 2010; Obuah 2010; Ohia, 2010), suggest cronyism in the appointment of the NSWG. This undermines their independence and disrupts the transparency and accountability objectives of NEITI.

The fact that Nigeria elects her president every four years, with a possibility of two term in office (section 135 (2) of the CFRN 1999) and the NSWG appointed every four years (S. 7, NEITI) gives every new president opportunity to appoint political supporters as NSWG members. And since the NSWG owe their appointment exclusively to the president their allegiance will be to the president and not to their constituencies. This position reduces the independence of NSWG and its efficacy as a stakeholder engagement platform (Arnstein, 1969; Schneider, 1999).

Also good stakeholder engagement requires that the stakeholders are well informed and empowered to take decisions (Arnstein, 1969; Schneider, 1999). However, the Act fails to meet this requirement in its criterion for appointment of NSWG members from the six geo-political zones of the country (see section 17 NEITI Act). The president can appoint anybody irrespective of their lack of capacity to understand the oil industry. If this happens, it will effectively disempower those NSWG and their constituencies as they would lack information for effective engagement (Arnstein, 1969). As put by NC;

I think the success of the NEITI will be judged on how effective communities are able to use this information to hold government and companies to account and to question them.

This implies that inability to access and understand information will result to inability to engage. This effectively undermines the professed objective of the NEITI Act.

However, ND disagrees and believes that the NSWG is strong. According to him

we have a very strong board, the strongest in all government organisations. ... The board is made up of radicals and civil society activists. It is difficult for anybody to manipulate any process.

Although ND perception of the present members may be true, the NEITI provisions still falls short of a coherent and effective regulation because it leaves itself to abuse and misinterpretation.However, not all NSWGmembers agree that they are effective in their NSWG role. For instance, according to NWSG1;

"I am not sure whether NEITI has changed anything in the society... I think we should emphasise more on tackling corruption, exposing it to the public and doing something about it and not necessarily targeting and getting validation.

This difference in opinion amongst the NEITI staff and even within the NSWG with regards to their effectiveness greatly suggests ineffective stakeholder engagement (Note 5).

\section{b. Enforcement}

Section 16 of the NEITI Act, makes it is an offence for a company or government official to render false accountings or delay in publishing accounting records that result to underpayment to the Federal Government. For companies, default may lead to a penalty of 200,000USD and possible revocation of license, upon advice of the NSWG [s.16 (1) (b)]. For company directors or government officials, a penalty of 30,000USD fine and or two years imprisonment on conviction [s.16 (5) and (6)].

However, NEITI does not have the power to arrest or prosecute defaulters. Only the office of the Attorney General of the Federation [AGF] can make this decision (Section 174, CFRN, 1999). This is a limitation. According to NC;

NEITI has ridiculously tremendous powers. It remains to be seen how they can enforce these powers.. It gives it ridiculously strong powers and authorities to look into accounts. But it will be interesting to see if it will be able to do even the basics.

NATLOG echoes these fears. He laments the inability of NEITI to enforce its provisions. According to NATLOG;

Actually the Act requires some reviews, because there are instances where companies fail us, NEITI doesn't have the mandate to demand for payments, we have to go through the regulatory agencies. 
This reliance on sister agencies raise some serious challenges for NEITI some of which the NEITI officials are already experiencing. NC pointed out this shortcoming when he stated that;

It is not clear in the Act how much power NEITI has over other government agencies because a lot of the gaps identified in the NEITI report so far are actually gaps in government agencies or government owned oil companies [...] I think that is one of the things that has really been holding up the successful implementation of NEITI. The problems that NEITI identified, NEITI can't solve, it is down to other government agencies to solve them.

The power to prosecute is one of such powers. Section 174 of the CFRN gives the AGF power to prosecute or delegate prosecution but there is nothing to show that this power has been delegated to NEITI. In fact, all the respondents were concerned that NEITI does not have the capacity to prosecute. In an earlier newspaper interview in response to the same issue, FNS stated that,

We have to go through the EFCC, the police and other relevant agencies. That's an impediment in the discharge of our duties. We have not gotten to the level of charging any offenders to court yet but that is not to say that we don't have any company that have defaulted (Economic Confidential, 2008a).

However, findings suggest an absence of collaboration with agencies that have the powers to arrest and prosecute. Expressing this lack of collaboration and its effect on the NEITI process, another respondent, NA, lamented thus;

When you are working with other agencies they feel you are trying to take away their powers, give them the powers but make sure they use it, we want results whoever uses it.

The 1999- 2004 NEITI audit confirm the same problem. NA also had an additional view why nobody has been prosecuted. He suggested it is because the law does not have a retrospective effect. In his own words;

We have not made any attempt to prosecute because the Act was passed in 2007 and our last audit was conducted for before 2005, so you can not prosecute in retrospect. We have not made any efforts or attempts to prosecute because the law does not cover that time.

But an NSWG member does not see any excuse for not prosecuting. He believes that the Act in its present state is not tenable. According to NSWG1;

I can tell you that up to this moment I am still trying to find out of what use we are to the society. I cannot see corruption and simply report it without doing anything about it. But this is what we are doing.

ND agrees with NSWG1. He believes that "NEITI does not have the power of enforcement, so for you to depend on other agencies to enforce the law is a problem".

Another respondent NSWG2 believes that NEITI can only be effective if it can enforce its provisions. According to him;

NEITI does not have rights to prosecute defaulters and this is where it is handicapped. I feel that if NEITI is empowered to take actions, it would have been much better. NEITI seem to be more of the need to get validation from EITI than actually fighting corruption

These ambiguities suggest lack of clarity in the NEITI provisions and it is a serious defect for any compulsory regulation.

\section{c. Transparency}

NEITI's engagement framework, provision of information for holding government accountable, ensuring that resources are channelled towards social development, are all hinged on the feasibility of transparency. Evidence suggests little has been gained in terms of transparency. This includes even in the appointment of a former NEITI secretary. According to one commentator,

The procedure for the appointment of the Executive Secretary is faulty. The requisite qualifications are unclear and there is no horizontal accountability. This has given rise to political cronies and clueless individuals to be appointed into such sensitive positions (Igwe, 2011).

Section 6 of the Act requires that the Secretary be an NSWG member with possible 5 year tenure. But in the contentious appointment, the secretary was appointed outside the NSWG members and seemingly creating a parallel power and of lack of horizontal accountability (Igwe, 2011). Also the Act requires the appointee be a graduate with ten years cognate experience without specifying the area. For a body whose purpose is to create transparency and clarity, such inelegant provisions only undermines its objective. One would have expected an unambiguous definition of a secretary like is obtained in the Companies and Allied Matters Act (CAMA) 1990 (Note 6). 
There are also the apparently contradictory confidentiality clauses in the Act. The provisions that "report shall not be published in a manner prejudicial to the contractual obligations or proprietary interests" (Sections 3(d) and (e); and 14(1), of audited companies looks like a deliberate attempt to forestall the objectives of the Act. Especially worrying is that "prejudicial" is not defined. It appears it is left for the company being audited to decide what is prejudicial. This is a major shortcoming of the NEITI Act; a situation that undermines the fundamental principle of transparency in the Act (Christian, 2010;Igwe, 2011).

The audit reports also disclosed deliberate attempts to hide information. An example is the inability of NEITI to get accurate readings of oil revenue (1999-2004 and 2005 Audits). There were discrepancies between NEITI's figures and those from the oil companies. Unfortunately, NEITI does not even have the facilities to independently and accurately make and support its findings; it has to rely on data provided by the oil companies. However, the 2005 audit report claims that volume of oil production reported by the oil companies is inaccurate leading to inaccurate calculation in revenue accrual. Additionally, in terms of data there appear to be little or no collaboration between agencies, especially between NEITI and DPR. In response to this issue, the FNS stated thus;

Actually, this has been the problem. It was one of the key issues that were highlighted in the 1999 to 2004 audit report. There's that problem of information flow between different arms (and agencies) of government (Economic Confidential, 2008b).

The reading of interview responses and other documents, discloses that transparency in the NEITI process appears to be a mirage. The complaints about the confidentiality provisions are most worrisome. These clauses appear to have effectively undermined the transparency principles of NEITI. The possibility that companies will use it as opportunity to obstruct justice through protracted preliminary court cases disguised as cases seeking definition of terms is high. In truth, there is no record of this happening yet. But if the usual lengthy court process is anything to go by; this is the approach that will soon emerge, especially as these companies have the resources to finance long-time court cases. Findings also suggest that even the available information is too technical and inaccessible to the public. The result is that there is no information against which to hold the government responsible. This defeats the transparency objective of NEITI.

\section{d. Accountability}

No person, private or corporate has been held to account by NEITI despite the general agreement that there are discrepancies in figures disclosed. The respondents and the official NEITI audit reports corroborate this finding. However, in a newspaper interview the former NEITI secretary appear to have contradictory information. When asked about the rate of compliance to NEITI, he answered $100 \%$. But when asked if NEITI has prosecuted anybody, he responded that only two companies had not complied, but that one has now complied leaving out one.

Also on government accountability, NEITI appears powerless. NEITI assumes it is the duty of civil society organizations, as representatives of stakeholders to pursue government accountability. On this question, NA responded thus;

Our activity has assisted to some extent in demanding for accountability because we work hand in hand with the civil societies; [...] they get privileged information about what resources have been collected by the federation. ...So it is for the civil societies to demand for accountability from the leaders (emphasis added).

This assumption arises from the fact that NEITI has no prosecutor or police powers. This means NEITI has to rely on the office of the Attorney General of the Federation (AGF) or the Economic and Financial Crimes Commission (EFCC) to enforce its provisions. This is not made clear in the NEITI Act and findings suggest this has been a major shortcoming of NEITI. Although NEITI has not indicted anybody, according to respondents, agency rivalry is going to be a big challenge. It is therefore necessary for the act to properly define the powers of NEITI on the enforcement of the NEITI Provisions.

The functionality of the NEITI act is in doubt. This is because enforcing the law may not be practical since NEITI has no facility to properly measure the revenue flow from individual companies. Without accurate information in this regard enforcing accounting will be arbitral and will leave room for corrupt practices. The 1999-2004 and 2005 audit reports support this analysis. The audit reports disclosed that NEITI could not reconcile accurately the revenue flow of the companies. Even some payments allegedly made to the government through the Central Bank of Nigeria could not be traced (NEITI audit, 1999-2004, and 2005).

To resolve this issue, the Act needs to categorically define what constitutes revenue and when calculation should begin. There have been suggestions that revenue flow should be equivalent to oil exploited and should be calculated from the wellhead (Igwe, 2011). This approach appears to be a good option. Getting accurate information will enable the government collect accurate data and provide a good idea of the amount of money lost 
via spillages and theft. It will also help the government decide whether to prosecute defaulters and especially, what to invest in preventing theft (Igwe, 2011).

\section{e. Social Development}

The government is yet to declare where it has invested the money, if any, realized from NEITI's activities. In fact since Obasanjo (1999-2007) left office, NEITI appears to have been shifted to the back burner (Muller, 2010). In fact it is only recently that NEITI increased its human capital. However, according to a respondent (a NEITI director), although NEITI's staff number has increased, "nothing can be done until capacity building programmes have been completed with staffs and communities have been sensitized as to the function and importance of NEITI".

However NEITI appear to have done a good job in laying good foundation for social development, particularly in demystifying the oil industry. NC thinks this is the case but conceded that the challenge is in making the information more understandable and less technical. In his own words,

The real challenge is enabling stakeholders to use this information to hold government and companies accountable.... They are very technical and complicated and in order to understand and use the information you have to be very technically and financially literate. I think it is a real challenge. I think the success of NEITI will be judged on how effective communities are able to use this information to hold government and companies to account and to question them.

His sentiments are echoed by all the respondents. They agree that NEITI has made good progress in opening up the industry to the public but that more still needs to be done to empower the stakeholders to use this information to hold government and corporations accountable so that the people can benefit from the social development promise of the petroleum industry. This aptly encapsulated in the words of NSWG3 thus;

I am not happy. I want NEITI to have more powers with which it can fight. NEITI is more interested in getting validation report, which has nothing to do with someone who needs a borehole in the village outside Abuja or in areas that need good roads. I think I would prefer to be a part of something that will make positive impact to the society. NEITI for now is still elitist

\section{Conclusion}

Using NEITI Act 2007 as a case study, this paper has examined the question whether compulsory regulation can improve CSR. This question was examined from the perspective of compulsory regulation being a tool for Stakeholder Engagement and social development. The research findings and discussion suggest compulsory regulation has great potentials for improving CSR. However, it appears that in this particular case, NEITI is yet to meet these potentials. NEITI appears to barely meet the accepted level of stakeholder engagement because of the lack of independence of stakeholders. This lack of independence in turn undermines transparency and accountability. The law also fails to satisfy its compulsory element but has been reduced to a token law.

However, the Act has some positive contributions. Most important is the general perception that NEITI's audit reports have made information on oil company payments and government receipts accessible for public scrutiny, albeit only to experts in the oil and gas industry. But analysis of the Act and its social environment suggests that compulsory regulation can only be a good CSR tool when it is created in an enforceable and transparent process. There is no need promulgating a law that is emasculated. For this particular Act, improvements can be made by increasing accountability and enforcement powers. As a contribution to the CSR and Regulation debate, this paper finds that compulsory regulation is not alien to CSR but needs to be defined, coherent, specific, and practicable.

This in no way depreciates the value of voluntary CSR whenever it is effective. It however, recognises that CSR when left as purely voluntary may fail to achieve its objective. It recognises that the concept of responsibility in CSR presupposes an expectation of accountability (Carroll, 1991; Baker, 2010; Bowen, 1953). It is this accountability that compulsory regulation can achieve particularly in extreme cases were voluntariness will not suffice (Utting, 2005; Wettstien, 2009) as incentive or motivation for social responsibility.

\section{Acknowledgement}

The author remains very grateful to the editor and reviewers for their meticulous reviews and advice and to Dr OnyekaOsuji for his helpful comments in the first draft. The author also thanks Miss Chika Onyesi for her help in the data collection stages. He is also grateful to his beautiful wife Bright Nnenna and lovely daughter ChidiebubeUgoeze for all their love, patience and support in all his endeavours and especially during his $\mathrm{PhD}$, from where this paper is adapted. The author is responsible for any and all errors. 


\section{References}

Arnstein, S.R. (1969). A ladder of citizen participation.American Institute of Planners, July, 216-224. Retrieved from http://lithgow-schmidt.dk/sherry-arnstein/ladder-of-citizen-participation.html

Awoniyi O. (2010). Nigeria, China sign $\$ 23$ bln refinery deal. AFP [online] $14^{\text {th }}$ May. Retrieved from http://www.google.com/hostednews/afp/article/ALeqM5gMFTqMPAD1RJhjW4qGyV16ZXK7Ww [accessed on 13th June 2010]

Baden, D.A., \& Harwood, I.A. (2010).Corporate social responsibility on trial: a panacea or fundamentally flawed concept? Paper presented at theBritish Academy of Management Conference 2010, Sheffield, GB14 16 Sep 2010.

Baker M. (2010). Corporate Social Responsibility - What does it mean? Retrieved from http://www.businessrespect.net/definition.php (January 14, 2010)

Balogun S. (2010). The Nigerian environment Favours corruption NEXT [online] $12^{\text {th }}$ June. Retrieved from http://234next.com/csp/cms/sites/Next/Home/5577398-146/story.csp (June 13, 2010)

BBC (2012). Nigeria ex-Delta state governor James Ibori guilty plea.BBC [online] 2 December. Retrieved from http://www.bbc.co.uk/news/world-africa-17181056 (March 8, 2012)

BBC News (2009). Nigeria dismisses James Ibori money laundering charges. BBC [online] 17 December.Retrieved from http://news.bbc.co.uk/1/hi/world/africa/8418302.stm (June 13, 2012)

BBC News (2010). Dick Cheney faces bribery scandal charges in Nigeria. BBC [online] 2 December. Retrieved from http://www.bbc.co.uk/news/world-africa-11902489 (February 18, 2011)

Bowen, H. R. (1953). Social Responsibilities of the Businessman. Harper \& Row: New York.

BPStatistical Review of World Energy June 2009. Retrieved from http://www.bp.com/liveassets/bp_internet/globalbp/globalbp_uk_english/reports_and_publications/statistica l_energy_review_2008/STAGING/local_assets/2009_downloads/statistical_review_of_world_energy_full_ report_2009.pdf (March 3, 2012)

Business Day (2010). AtikuAbubakar in $\$ 40$ Million money-laundry Accusations. BusinessDay. [online] $5^{\text {th }}$ February. Retrieved

from http://www.businessdayonline.com/index.php?option=com_content\&view=article\&id=8190:us-atiku-abuba kar-in-40m-money-laundering-accusation-\&catid=1:latest-news\&Itemid=18 (June 13, 2010)

Carroll, Archie B. (1991). The pyramid of corporate social responsibility: toward the moral management of organizational stakeholders - balancing economic, legal, and social responsibilities. Business Horizons. http://dx.doi.org/10.1016/0007-6813(91)90005-G

Christian O. (2010). Nigeria's broke, says Revenue Commission boss, The Daily Sun. [online]. Retrieved from http://www.sunnewsonline.com/webpages/news/national/2010/apr/19/national-19-04-2010-001.htm accesse d on the 23/04/2010 (December 28, 2010)

Commission of the European communities. (2006). Communication from the Commission to the European Parliament, the Council and European Economic and Social Committee, Implementing the partnership for growth and jobs: Making Europe a pole of Excellence on Corporate Social Responsibility. [March] Brussels Retrieved from http://eurlex.europa.eu/LexUriServ/LexUriServ.do?uri=COM:2006:0136:FIN:EN:PDF (May 10, 2010)

De Vaus, D. A. (2002). Surveys in Social research $5^{\text {th }}$ Edition, Australia

Deegan, C. (2002). Introduction: The legitimising effect of social and environmental disclosures - a theoretical foundation. AAJ, 3(15), 282-311. Retrieved from http://www.emeraldinsight.com/0951-357.htm (November 14, 2009)

Deegan, C., \& Rankin, M. (1996). Do Australian companies report environmental news objectively? An analysis of environmental disclosures by firms prosecuted successfully by the Environmental Protection Authority. $\begin{array}{lllll}\text { Accounting, Auditing \& Accountability Journal, } & \text { 9(2), } & \text { pp.52-69 }\end{array}$ http://dx.doi.org/10.1108/09513579610116358

Department for Business Innovation and Skills [DBIS]. (2009). The Benefits of Regulation: A public and business perceptions study. October 2009, URN 09/1403. Retrieved from http://www.bis.gov.uk/files/file53236.pdf ( February 14, 2011) 
Donovan J. (2010). Controversies surrounding Royal Dutch Shell. Retrieved from http://royaldutchshellplc.com/2010/09/27/controversies-surrounding-royal-dutch-shell-2/ (December 17, 2010)

Easterby-Smith, M., Thorpe, R \& Jackson Paul R. (2008). Management Research. (3 ${ }^{\text {rd }}$ ed) Sage, Los Angeles

Economic Confidential (2008a). One oil company defaulted to audit enquiry -HarunaSaeed, NEITI Boss. [online] available http://www.economicconfidential.com/x/index.php?option=com_content\&view=article\&id=138:economicconfidential\&catid=6:exclusive-interviews\&Itemid=4 (January 24, 2011)

Economic Confidential (2008b). Nigeria doesn’t know Exact Oil Productions - NEITI Boss, Retrieved from http://www.economicconfidential.com/x/index.php?option=com_content\&view=article\&id=231:nigeria-do esnt-know-exact-oil-productions--neiti-boss\&catid=6:exclusive-interviews\&Itemid=4 (May 10, 2010)

Ed Kashi (2010). Curse of the black gold: 50 years of oil in the Niger Delta. $10^{\text {th }}$ March, Guardian.Retrieved from http://www.guardian.co.uk/environment/gallery/2010/mar/05/curse-black-gold-nigeria (May 10, 2010)

Elsbach K. D. (1994). Managing organizational legitimacy in the California cattle industry: The construction and effectiveness of verbal accounts', Administrative Science Quarterly 39:57-88. http://dx.doi.org/10.2307/2393494

European Commission (2001). Promoting a European framework for Corporate Social Responsibility: green paper. Luxembourg: Office for official publication of the European Communities

Eweje, G. (2006). The Role of MNE’s in Community Development Initiatives in Developing countries: CSR at work in Nigeria and South Africa. Business and Society (June). 45(2) , 93-129, 113

Extractive Industries Transparency Initiative (EITI).Retrieved from www.eiti.org

Frankental, P. (2001). Corporate social responsibility - a PR invention? Corporate Communications: An International Journal , 6(1), pp: 18-23. http://dx.doi.org/10.1108/13563280110381170

Freeman (2001). Stakeholder theory for the modern corporation in Hoffman W M, Frederick R E,Scwartz M S (eds), Business Ethics: Reading and Cases in Morality, (4 ${ }^{\text {th }}$ edn) McGraw Hill Boston, M A

Frynas, J.G. (2005). The false developmental promise of Corporate Social Responsibility: Evidence from multinational oil companies. International Affairs $81, \quad 3 \quad$ (2005) $581 \quad$ - 598. http://dx.doi.org/10.1111/j.1468-2346.2005.00470.x

Gatto, Alexander C. (2002). The European Union and Corporate Social Responsibility: Can the E U contribute to the Accountability of Multinational Enterprise? Institute of International Law, Working Paper No 32 September. Retrieved from https://www.law.kuleuven.be/iir/nl/onderzoek/wp/WP32e.pdf ( February 14, 2011)

Glaser E., \& Gyourko J. (2002). Zoning’s steep prices. Regulation, Fall

Guthrie, J., \& Parker, L. D. (1989). Corporate social reporting: a rebuttal of legitimacy theory. Accounting and Business Research, 19(76), pp.343-52. http://dx.doi.org/10.1080/00014788.1989.9728863

Her Majesty's Revenue and Customs [HMRC] (n.d). Income Tax rates and allowances. Retrieved from http://www.hmrc.gov.uk/rates/it.htm (February 1, 2011)

Igwe U. (2011). Nigeria EITI: After validation, what next? Weekend Observer [online] 22bnd January. Retrieved fromhttp://www.nigerianobservernews.com/15012011/weekendobserver/features/4.html (January 23, 2011)

IRIN(n.d.). NIGERIA: Govt hits tobacco companies with whopping law suit. Retrieved fromhttp://www.irinnews.org/report.aspx?ReportID=75239( June 7, 2010)

McGuire J. W. (1963). Business and Society. New York, McGraw Hill

NEITI Handbook (2005). Retrieved from www.neiti.org.ng [online], [accessed on the 27/12/2009]

Neu, D., Warsame, H., \& Pedwell, K. (1998). Managing public impressions: Environmental disclosures in annual report. Accounting, Organizations and Society, 23(3), pp.265-82. http://dx.doi.org/10.1016/S0361-3682(97)00008-1

Nigerian Budget (2009). Retrieved from http://www.fmf.gov.ng/Budget2009Info/2009budgetfinalSpeach.pdf (March 8, 2010) 
Nigerian Extractive Industries Transparency Initiative (2006). Nigerian Extractive Industries Transparency Initiative: Audit of the period 1999-2004 (popular version). Retrieved from http://www.neiti.org.ng/files-pdf/PopularVersionof1stAudit.pdf (March 8, 2010)

Nigerian Extractive Industries Transparency Initiative (2008). Nigerian Extractive Industries Transparency Initiative (NEITI), Physical Audit 2005, Final Draft Report Retrieved from http://www.neiti.org.ng/2005\%20Audit\%20Reports/NEITIPhysicalAudit2005-FinalDraftReport.pdf (March 8, 2010)

Obuah, E. (2010). Combating corruption in a failed state: The Nigerian Economic and Financial Crimes Commission (EFCC). Journal of Sustainable Development in Africa, 12(1). Retrieved from http://jsd-africa.com/Jsda/V12NO1_Spring2010_A/PDF/Combating\%20Corruption\%20in\%20a\%20Failed \%20State.pdf (May 26, 2010)

Ohia P. (2010). UK Convicts Ibori's Associate, Udoamaka, Thisdayonline. Retrieved from http://www.thisdayonline.com/nview.php?id=174842 (June 13, 2010)

Patton, M. Q. (2002). Qualitative evaluation and research methods (3rd ed.). Thousand Oaks, CA: Sage Publications, Inc

Permanent Mission of Nigeria to the United Nations Website. Retrieved from http://www.nigeriaunmission.org/index.php?option=com_content\&view=article\&id=47\&Itemid=54 (June 14, 2010)

Powell, W. W., \& P. J. DiMaggio (eds.), (1991). The New Institutionalism in Organizational Analysis. University of Chicago, Chicago

Pritchard A. C.(2003). Self-Regulation and Securities Markets. Regulation, Spring

Sahara Reports (2010). US: AtikuAbubakar in \$40 Million money-laundry Accusations with wife, Jennifer. Sahara Reports. Retrieved from http://www.saharareporters.com/real-news/srr-headlines/5049-us-atiku-abubakar-in-40million-money-laund ering-accusation-with-wife-jennifer.html (June 13, 2010)

Schneider H. (1999). Participatory governance for poverty reduction. Journal of international development, 11, 521-534

Shaxson, N. (2009). Nigeria Extractive Industries Transparency Initiative: Just a glorious audit? Chatham House.Retrieved from http://www.chathamhouse.org.uk/files/15223_1109neiti.pdf ( December 28, 2009)

Shocker, A. D., \& Sethi, S. P. (1974). An Approach to Incorporating Social Preferences in Developing Corporate Action Strategies, in Sethi, S. P., (ed.), The unstable ground: Corporate Social Policy in a Dynamic Society, Melville Publishing Company, Los Angeles, pp. 67-80.

Silverman, D. (2006). Interpreting qualitative data: methods for analyzing talk, text and interaction, 3rd ed. Sage London

Singh M. P. (2010). Bhopal court to pronounce historic judgment in gas leak case on Monday. $6^{\text {th }}$ June, The Hindu.Retrieved from http://beta.thehindu.com/news/national/article447628.ece (June 29, 2010)

Sotirios, S. (1998). Social research. $2^{\text {nd }}$ ed. Palgrave

Suchman, M. C. (1995). Managing legitimacy: strategic and institutional approaches, Academy of management review 20/3: 571-610

The World Bank Report (2010). Doing Business in Nigeria 2010.World Bank and International Finance Corporation. Retrieved from http://www.doingbusiness.org/Documents/Subnational/DB10-Nigeria.pdf ( June 14, 2010)

The World Bank, Nigeria: Country Brief. Retrieved from http://web.worldbank.org/WBSITE/EXTERNAL/COUNTRIES/AFRICAEXT/NIGERIAEXTN/0,,menuPK :368906 pagePK:141132 piPK:141107 theSitePK:368896,00.html (June 14, 2010)

Tuodolo, O.F. (2007). Corporate Social Responsibility, Local Communities and TNCs in the Oil and Gas Sector of Nigeria. PhD Thesis (unpublished), University of Liverpool, UK.

Tuzzolino, F., \& Armandi, B. (1981). A Need Hierarchy Framework for Assessing CSR. American Management Review 6 21-28, p 24 
Utting, P., (2005). Rethinking Business Regulation: From Self-Regulation to Social Control Technology. Business and Society Programme Paper, Number 15, September

Vines A, Wong L, Weimer M \& Campos I. (2009). Thirst for African Oil Asian National Oil Companies in Nigeria and Angola, A Chatham House Report. Retrieved from http://www.voltairenet.org/IMG/prdf/Thirst_for_African_Oil.pdf (December 28, 2009)

Wettstien F. (2009). Beyond voluntariness, beyond CSR: Making a case for human rights and justice Business and Society Review 114:1 125-1

\section{Notes}

Note 1. The crisis caused by the sale of illegal blood diamond in Congo and Sierra Leone, exploitative oil exploration in Nigeria, and Speculative investments that lead to the recent global financial crisis attest to need for effective regulation.

Note 2. In Wiwa v Royal Dutch Petroleum ltd (226 F 3d 88 2D Cir 2000), the defendant allegedly used the state military forces to commit torture, imprisonment and killing of the plaintiffs and their relatives.

Note 3. In the Bhopal cases over 20,000 allegedly died from gas poisoning resulting from the alleged criminal negligence of the company Union Carbide India Ltd

Note 4. RMAFC is established by section 153 of the CFRN 1999, and mandated in the 3rd Schedule, section 32 to monitor the accruals to and disbursement of revenue from the Federation Account, and review, from time to time, the revenue allocation formulae and principles in operation to ensure conformity with changing realities.

Note 5. A further study may be required that will concentrate on the effectiveness of the stakeholder engagement role of the NSWG. A better study may have to wait until a new set of NSWG members are appointed and the results of the recent audit report is publish. This will time frame and report will enable a more robust data for analysis.

Note 6. The CAMA provides that an individual appointed as the secretary of a public company must be a lawyer, a chartered accountant or secretary or qualified by experience (worked as secretary for at least 3 of 5 years before incorporation of the company). This ensures that only a competent individual is appointed. 